\title{
ANALISIS VIDEO YOUTUBE SEBAGAI SARANA KOMUNIKASI
}

\author{
Floriantiana Elinsa carda
}

Elinsacarda2019@gmail.com

\begin{abstract}
The purpose of this research are: (1) To find out how the community of Makassarvidgram utilize YouTube as a media of communication; (2) To find out what are the strengths and weaknesses youtube as a media of communication for the community of Makassarvidgram. This research was conducted for approximately thr ee months, ie May-July 2016 which was held in the city of Makassar. The population of this research is Makassar vidgram community. The respondents of this research are determined at random on some community members joined in Makassar vidgram. This type of research uses a qualitative method by using the theory of New Media as a research platform. Mechanical depth interviews with informants to collect primary data. Secondary data is done by observation, library research both from books and Internet sites that are relevant to the focus of the problem. The results showed that the use youtube as a means of communication for Communities Makassarvidgram categorized quite helpfull. The response of the informants regarding the advantages and disadvantages are more $t$

o the excess one, that will make youtube looks very priceless, effective and efficient as a communication media for this community.
\end{abstract}

\section{ABSTRAK}

Skripsi ini bertujuan untuk : (1) untuk mengetahui bagaimana komunitas Makassarvidgram memanfaatkan Youtube sebagai sarana komunikasi; (2) untuk mengetahui apa saja kelebihan dan kelemahan youtube sebagai suatu sarana komunikasi bagi komunitas Makassarvidgram.Penelitian ini dilakukan selama kurang lebih tiga bulan, yaitu mei-juli 2016 yang dilaksanakan di Kota Makassar. Adapun populasi penelitian ini adalah komunitas Makassar vidgram. Responden penelitian ini ditentukan secara acak pada beberapa anggota yang tergabung dalam komunitas Makassar vidgram. Tipe peneli tian ini menggunakan metode kualitatif dengan menggunakan teori New Media sebagai landasan penelitian. Teknik wawancara mendalam terhadap narasumber untuk mengumpulkan data primer. Data sekunder dilakukan dengan observasi, studi pustaka baik itu dari buku-buku, dan situs internet yang relevan dengan focus permasalahan. Hasil penelitian menunjukkan bahwa pemanfaatan youtube sebagai sarana komunikasi bagi Komunitas Makassarvidgram termasuk kategori cukup membantu. Penelitian ini juga menemukan karakteristik youtube berdasarkan pemanfaatan yang dirasakan oleh penggunanya, berdasarkan masing-masing kebutuhan pengguna Respon dari para informan mengenai kelebihan dan kekurangan youtube sebagai sarana komunikasi yang lebih condong pada kelebihannya, membuat youtube 
ternilai sangat efektif dan efisien sebagai sarana komunikasi bagi komunitas in

\author{
keywords: Youtube; Sarana Komunikasi;Makassarvidgram
}

\title{
1. PENDAHULUAN
}

YouTube adalah sebuah situs web video sharing (berbagi video) yang populer dimana para pengguna dapat memuat, menonton, dan berbagi klip video secara gratis. Didirikan pada bulan februari 2005 oleh 3 orang mantan karyawan PayPal, yaitu Chad Hurley, Steve Chen dan Jawed Karim. Umumnya video-video di YouTube adalah video klip film, TV, serta video buatan para penggunanya sendiri. (Tjanatjantia. Widika, 2013)

Salah satu layanan dari Google ini, memfasilitasi penggunanya untuk meng- upload video dan bisa diakses oleh pengguna yang lain dari seluruh dunia secara gratis. Bisa dikatakan YouTube adalah database video yang paling populer di dunia internet, atau bahkan mungkin yang paling lengkap dan variatif. Pada awalnya YouTube memang bukan dikembangkan oleh Google, tapi Google mengakuisinya lalu kemudian menggabungkannya dengan layananlayanan Google yang lain.

Saat ini Youtube menjadi situs online Video provider paling dominan di Amerika serikat, bahkan dunia, dengan menguasai 43\% pasar. Diperkirakan 20 Jam durasi video di upload ke Youtube setiap menitnya dengan 6 miliar views per hari. Youtube kini telah menjadi berbagai macam kebutuhan dari penggunanya, fitur- fitur yang ditawarkan dengan kemajuan teknologi Youtube saat ini sangat membantu dari berbagai aspek kebutuhan yang dibutuhkan sang pengguna.

Memiliki lebih dari satu miliar pengguna, hampir sepertiga dari semua pengguna internet dan setiap hari orang menonton ratusan juta jam video di YouTube dan menghasilkan miliaran kali penayangan. YouTube secara keseluruhan, telah menjangkau lebih banyak pemirsa yang berusia 18-34 dan 18-49 tahun daripada jaringan kabel mana pun di Dunia. Jumlah jam yang diluangkan orang- orang untuk menonton video (alias waktu tonton) di YouTube naik $60 \%$ per tahunnya, dan merupakan pertumbuhan terpesat yang pernah dilihat dalam kurun waktu 2 tahun terakhir. Jumlah orang yang menonton YouTube per hari naik sebesar 40\% per tahun sejak Maret 2014.Jumlah pengguna yang mengunjungi YouTube dan memulainya dari beranda YouTube, naik lebih dari 3 kali lipat per tahun. (youtube, 2016)

Ada 14 Web Video Selain YouTube yang berkembang di dunia maya saat ini diantaranya : Metacafe, Yahoo! Screen, Dailymotion, Vuclip, Vimeo, Hulu, Metatube, MyVideo.de, Sidereel.com, Youku.com Tudou.com, Kivvi.kz, Blip.tv,

Veoh.com. Namun di antara ke 14 tersebut Youtube tetaplah menjadi pilihan utama ketika ingin mengunjungi laman video sharing.

Sebagai perbandingan (DeCesare, 2014) mengatakan YouTube dan Vimeo adalah sumber daya yang sangat baik untuk video online. Situs ini sangat berbeda dalam penawaran mereka untuk pengguna upload. Panjang video, penonton, dan alat-alat yang tersedia bervariasi. "Streaming Resources Video untuk Pengajaran, Learning, dan Penelitian," akan juga mencakup beberapa sangat baik akses terbuka, seluruh negara bagian, dan inisiatif video online kelembagaan, serta interdisipliner situs dengan koleksi video online besar dalam berbagai kategori dan topik. . 
Penelitian kali ini, penulis mengambil sampel yaitu Komunitas Makassar Video Instagram atau Makassarvidgram. Komunitas yang dikembangkan oleh anak- anak muda Makassar ini, berdiri sejak tahun 2014 ini sudah memiliki anggota aktif sekitar 80 orang. Di kategorikan dalam dua kelompok yaitu kategori "Watcher" atau penonton dan "Creator" atau si pembuat dari videovideo tersebut. Komunitas yang aktif dalam memproduksi video-video singkat berdurasi 15 detik ini, banyak menggunakan youtube sebagai sarana komunikasi dan juga tempat sharing video. Namun berbeda dengan instagram, durasi yang di unggah pada Youtube pun berbeda.

\section{TINJAUAN PUSTAKA}

Terdapat karakteristik dari youtube yang membuat banyak dari sebagian pengguna betah menggunakannya. Berdasarkan hasil wawancara kepada para informan dan penelitian yang dilakukan,penulis mengelompokkan menjadi5 bagian :

1.Tidak ada batasan durasi untuk mengunggah video. Hal ini yang membedakan youtube dengan beberapa aplikasi lain yang mempunyai batasan durasi minimal waktu semisal instagram, snapchat, dan sebagainya.

2.System pengamanan yang mulai akurat. Youtube membatasi pengamanannya dengan tidak mengizinkan video yang mengandung sara, illegal, dan akan memberikan pert anyaan konfirmasi sebelum menggunggah video.

3.Berbayar. Saat ini seperti yang sedang menjadi viral dimana-dimana, youtube memberikan penawaran bagi siapapun yang mengunggah videonya ke youtube dan mendapatkan minimal 1000 viewers atau penonton maka akan diberikan honorarium. (Theoldman, 2011)

4.System offline. Youtube mempunyai fitur baru bagi para pengguna untuk menonton videonya yaitu system offline. System ini memudahkan para pengguna untuk memonton videonya pada saat offline tetapi sebelumnya video tersebut harus didownload terlebih dahulu. 5.Tersedia editor sederhana. Pada menu awal mengunggah video, pengguna akan ditawarkan untuk mengedit videonya terlebih dahulu. Menu yang ditawarkan adalah memotong video, memfilter warna, atau menambah efek perpindahan video.

\section{METODE}

a. Waktu dan Tempat Penelitian

Waktu penelitian akan berlangsung sekitar 2-3 bulan, yaitu dimulai pada bulan Maret hingga Mei 2016. Lokasi penelitian akan dilakukan sesuai lokasi pertemuan MakassarVidGram (disesuaikan).Teknik Penentuan Informan

Informan dalam penelitian ini dipilih dengan menggunakan Non-Probability Sampling yaitu sampel dipilih sebagai informan berdasarkan pertimbangan tertentu yaitu mampu memberikan data dan informasi yang dibutuhkan dalam penelitian ini. Informan yang dipilih pada penelitian kali ini yaitu Komunitas Makassar Video Instagram (MakassarVidGram).

Teknik Pengumpulan Data

a.Data Primer

1.Wawancara Mendalam (Depth Interview)

Metode wawancara yang peneliti gunakan yaitu wawancara mendalam karena penelitian ini merupakan penelitian kualitatif. Wawancara akan dilakukan dengan informan 
yang telah dipilih dengan mengajukan pertanyaan mulai dari yang umum hingga yang lebih mendalam.

2.Observasi

Selain wawancara mendalam, peneliti juga akan melakukan observasi lapang.. Observasi yang dilakukan adalah observasi Non-Participasi dimana dalam observasi ini peneliti hanya mengamati dan tidak berpatisipasi dalam proses kerja.

b.Data Sekunder

Dokumentasi adalah salah satu metode pengumpulan data kualitatif dengan melihat atau menganalisis hasil-hasil kerja yang dibuat oleh informan. Dokumen tersebut dapat berupa catatan harian, dokumen resmi internal maupun eksternal.

\section{HASIL}

Penelitian ini dilakukan di Kota Makassar terhadap Komunitas Makassarvidgram yang menggunakan youtube sebagai sarana komunikasinya. Peneliti melakukan ekplorasi mendalam agar dapat menjawab pertanyaan penelitian, yaitu bagaimana pemanfaatan youtube sebagai sarana komunikasi bagi komunitas MakassarVidgram. Informasi yang diperoleh dalam penelitian ini bersumber dari hasil wawancara langsung.

Dengan kemampuan untuk membuat dan mengunggah video baik grafis maupun animasi, peluang baru terbuka pada setiap orang untuk memperluas pengajaran mereka dengan berbagai gaya komunikasi yang dapat diimplementasikan.(Roodt, 2013)

Peneliti mengajukan beberapa pertanyaan yang terkait dengan permasalahan yang diteliti dan telah disusun untuk diajukan kepada informan penelitian.

\section{PEMBAHASAN}

Youtube sebagai sarana komunikasi

Youtube merupakan sebuah wujud dari salah satu social media yang masuk kedalam kategori Media Baru. Media baru sendiri merupakan bagian dari teori komunikasi massa, dimana komunikasi massa adalah komunikasi yang menggunakan media massa dalam penyampaian infromasi kepada khalayak

banyak. Berdasarkan macam-macam teori komunikasi massa, media baru masuk sebagai salah satu kategori yakni media yang mempunyai ciri khas yang menonjol dalam penggunaan membiaskan massa historis apapun, mengikat waktu, dan mengikat ruang. Dimana media tersebut muncul sebagai sebuah pikiran manusia yang diciptakan untuk memaksakan manusia dikuasai oleh media. Teori ini juga berkaitan dengan teori kritis, dimana media dijadikan alat untuk kepentingan hiburan, politik, informasi, Entertaiment. Jadi teori new media baru muncul kemudian setelah teori komunikasi massa berkembang.

Dikaitkan dengan teori uses and gratification yang juga merupakan bagian dari Teori Komunikasi Massa, menurut Herbert Blummer dan Elihu Katz , Teori uses and gratifications (kegunaan dan kepuasan dalam bukunya The Uses on Mass Communications: Current Perspectives on Gratification Research mengatakan bahwa 
pengguna media memainkan peran aktif untuk memilih dan menggunakan media tersebut. Dengan kata lain, pengguna media adalah pihak yang aktif dalam proses komunikasi. Pengguna media berusaha untuk mencari sumber media yang paling baik di dalam usaha memenuhi kebutuhannya. Artinya, teori ini mengasumsikan bahwa penngguna mempunyai pilihan alternatif untuk memuaskan kebutuhannya.

Ada beberapa asumsi dasar tentang teori

Uses and Gratification ini, diantaranya :

1. Audiens adalah aktif, dan penggunaan media berorientasi pada tujuan.

2. Inisiative yang menghubungkan antara kebutuhan kepuasan dan pilihan media spesifik terletak di tangan audiens

3. Media bersaing dengan sumber-sumber lain dalam upaya memuaskan kebutuhan audiens

4. Orang-orang mempunyai kesadaran-diri yang memadai berkenaan penggunaan media, kepentingan dan motivasinya yang menjadi bukti bagi peneliti tentang gambaran keakuratan penggunaan itu.

5. Nilai pertimbangan seputar keperluan audiens tentang media spesifik atau isi harus dibentuk.

Berbeda dengan teori media baru, Teori ini lebih menekankan pada pendekatan manusiawi dalam melihat media massa. Artinya, menusia itu mempunyai otonomi, wewenang untuk memperlakukan media. Menurut pendapat teori ini, konsumen media mempunyai kebebasan untuk memutuskan bagaimana (lewat media mana) mereka menggunakan media dan bagaimana media itu akan berdampak pada dirinya. Teori ini juga menyatakan bahwa media dapat mempunyai pengaruh jahat dalam kehidupan.

Kita bisa memahami interaksi orang dengan media melalui pemanfaatan media oleh orang itu(uses) dan kepuasan yang

\begin{tabular}{|c|c|c|}
\hline COME & ART & FOOD \\
DY & $2,3 \%$ & $2,3 \%$ \\
$9,5 \%$ & & \\
\hline BEAUT & TRAVEL & SPORT \\
$Y$ & LI NG & $2,3 \%$ \\
$2,3 \%$ & $2,3 \%$ & \\
\hline
\end{tabular}

diperoleh (gratification). Gratifikasi yang sifatnya umum antara lain pelarian dari rasa khawatir, peredaan rasa kesepian, dukungan emosional, perolehan informasi, dan kontak sosial. Sama halnya dengan komunitas makassarvidgram yang memilih media youtube sebagai salah satu media

dengan menyalurkan rasa humor masyarakat Makassar.

1. Kelebihan dan kekurangan youtube sebagai sarana komunikasi 
Terlepas dari segala konten yang tersedia diyoutube, sekiranya tak selalu menjadi sempurna sesuatu hal. Walaupun saat ini youtube masih menjadi primadona saat memilih video laman sharing, namun hal itu juga tak terlepas dari berbagai macam kekurangan yang terdapat pada social media laman video sharing tersebut. Karena kebutuhan dari masing-masing individu dalam pencariannya berbeda-beda pada youtube, maka sesuai komunitas makassarvidgram dibagi menjadi beberapa bagian, diantaranya :

Dengan persentase repost atau mengupload ulang video dilaman akun instagram pada table diatas, dalam seminggu video komedi mendapat bagian untuk di repost kembali sebanyak 4 kali, sedangkan video lainnya hanya bisa di repost kembali sekali dalam seminggu.

Rumus umum :

Misalkan $\mathrm{n}=$ jumlah repost per kategori

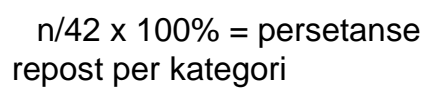

Hasilnya :

$4 / 42 \times 100 \%=9.5 \%$ (Besarnya minat viewers terhadap video komedi)

$1 / 42 \times 100 \%=2.3 \%$ (Besarnya minat viewers pada tema video lainnya)

Table 1. Pembagian video harian yang direpost

Dimasukan dalam perkalian sederhana, video komedi mempunyai persentasi $9.2 \%$ sedangkan video lainnya hanya mendapatkan $2.3 \%$. Ketentuan merepost ini ditentukan sesuai dari banyaknya permintaan dari followers atau pengikut- yang dipilih sebagai sarana komunikasi

pengikut aktif dari Instagram Makassarvidgram saat ini.

Jadi bisa dikatakan dikalangan komunitas makassarvidgram, youtube sangat berguna bagi sarana komunikasi dalam hal mengembangkan karya-karya mereka dalam membuat video-video singkat mereka, yang kemudian diperlihatkan didunia maya.

\section{KESIMPULAN}

Berdasarkan hasil penelitian yang dilakukan oleh penulis tentang Youtube sebagai sarana komunikasi bagi Komunitas Makassarvidgram, maka ada beberapa hal yang perlu disimpulkan antara lain sebagai berikut: 1.Youtube sangat bermanfaat bagi anggota komunitas Makassarvidgram.Pemanfaatan yang dilakukanpun disesuaikan dengan masingmasing kebutuhan dari para informan. ada yang menggunakannya untuk keperluan video mereka, baik dari segi pencarian tools editing, referensi ide, tutorial, maupun untuk kepentingan hiburan.

2.Kelebihan dan kekurangan dari masing-masing informan pun berbeda. Ada yang mengatakan bahwa segala kebutuhan pencariannya terpenuhi ketika ia melakukan pencarian video-video diyoutube, ada juga yang memang menunggu video yang hanya tersedia di youtube.

3.Belum semua dari informan yang menggunakan youtube sebagai media eksistensi diri mereka layaknya instagram, hanya beberapa diantara mereka yang menggunakannya. Hal itulantaran mereka masih senang berkutat dengan 
video berdurasi singkat yang sesuai dengan durasi yang diberikan oleh youtube. Tak lain juga menyangkut komunitas ini yang juga berfokus pada instagram sebagai media penyaluran video-video mereka

\section{DAFTAR PUSTAKA}

DeCesare, J. A. (2014). User Uploads and YouTube One Channels for Teaching, Learning, and Research. Library Technology Reports.

McQuail, D. (2011). Teori Komunikasi Massa. Jakarta: Salemba Humanika.

Roiu, G. L. Ă. Z. Ă. (2008). New media versus news media, 3(3), 76-84.

Roodt, S. (2013). Using YouTube to Support Student Engagement for the Net Generation in Higher Education. 1977(December 1977), 223-231. Retrieved from http://search.ebscohost.com/login.aspx ?dir ect=true $\& d b=b t h \& A N=87385180 \&$ site $=e$ host-live

Tjanatjantia. Widika. (2013). Sejarah Berdirinya Youtube _ Sejarah Dunia. Retrieved from

https://canacantya.wordpress.com/sejarah/ sejarah-berdirinya-Youtube

Tugas 2:

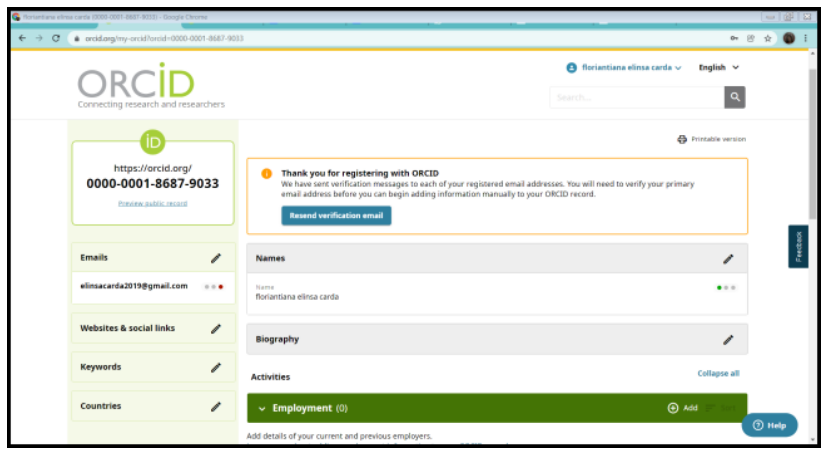

